\title{
Analisis Perbedaan Belajar Terhadap Siswa yang Berasal Dari Keluarga Broken Home
}

\author{
Nur Ermayani ${ }^{1}$, Nurhasela ${ }^{2}$, Lusi Marleni ${ }^{3}$ \\ Prodi Pendidikan Bahasa Inggris \\ Fakultas Ilmu Pendidikan \\ Universitas Pahlawan Tuanku Tambusai \\ Email : nurermayani161@gmil.com ${ }^{1}$, nurhasella28@gmail.com ${ }^{2}$
}

\begin{abstract}
Abstrak
Penelitian ini dilatar belakangi oleh Kesulitan belajar pada anak yang tinggal dalam keluarga broken home. Tempat penelitian ini dilakukan di Universitas Pahlawan Bangkinang dan di SMAN 1 KUOK. Dengan sampel penelitian, subjek 1. Mahasiswa ini tidak memiliki keluarga utuh disebabkan karena salah satu orang tuanya meninggal (ayah). Subjek 2. Siswa broken home yang mana orang tuanya sudah bercerai. Metodologi penelitian ini berbentuk studi kasus yaitu suatu penelitian kualitatif yang menghasilkan data deskriptif berupa ucapan (lisan). Teknik pengumpulan data penelitian ini adalah observasi, wawancara dan analysis dokumen. Subjek penelitian adalah dua anak yang hidup dalam keluarga broken home yang memiliki perbedaan prestasi. Hasil penelitian menunjukkan adanya perbedaan antara siswa yang berasal dari keluarga broken home, ada siswa yang berprestasi tinggi, berperilaku sangat baik dan siswa yang berprestasi rendah, berprilaku minim. Siswa yang berasal dari keluarga broken home memiliki minat belajar yang tinggi, mereka senang dengan materi pembelajaran yang ia sukai. Siswa yang memiliki minat belajar yang rendah, merasa tidak senang dengan kebanyakan materi pembelajaran, dia hanya fokus belajar jika materi yang di pelajari adalah materi yang paling dia senangi. Kesimpulan dari penelitian ini adalah perbedaan prestasi antara siswa yang berasal dari keluarga broken home. Ada siswa yang berprestasi tinggi dan ada siswa yang berprestasi rendah.
\end{abstract}

Kata kunci: Perbedaan belajar, Siswa, Minat Belajar.

\begin{abstract}
This research was motivated by the learning difficulties of children living in broken homes. The place where this research was conducted was at the Bangkinang Hero University and at SMAN 1 KUOK. With the research sample, subject 1 . This student does not have a complete family because one of his parents died (father). Subject 2. Broken home students whose parents are divorced. This research methodology is in the form of a case study, which is a qualitative research that produces descriptive data in the form of speech (oral). The data collection techniques of this research are observation, interview and document analysis. The subjects of the study were two children living in broken home families who have different achievements. The results showed that there were differences between students who came from broken home families, there were students who had high achievement, had very good behavior and students who had low achievement, had minimal behavior. Students who come from broken home families have a high interest in learning, they feel happy with the learning materials they like. Students who have low interest in learning, feel unhappy with most of the learning material, they only focus on learning if the material being studied is the material they enjoy the most. The conclusion of this study is the difference in achievement between students who come from broken home families. There are students who have high achievement and there are students who have low achievement
\end{abstract}

Keywords: Differences in learning, students, interest in learning. 


\section{PENDAHULUAN}

Pendidikan adalah hal penting yang menjadi pondasi atau tonggak hidup seseorang yang harus dibangun sebaik mungkin dengan tujuan agar setiap orang dapat memiliki pengetahuan, kreativitas dan kepribadian yang lebih bertanggung jawab. Dalam dunia pendidikan, proses belajar perlu diperhatikan karena berpengaruh pada berhasil atau tidaknya seorang siswa. Dalam berlangsungnya proses belajar, prestasi belajar pada masing-masing siswa juga berbeda. Ada siswa yang pintar, siswa yang cerdas, siswa yang biasa-biasa saja, bahkan ada juga siswa yang lemah IQ-nya. Perbedaan ini terjadi karena beberapa faktor salah satunya faktor lingkungan keluarga. Keluarga merupakan tempat pertama dimulainya dunia pendidikan. Dalam lingkungan keluarga, seorang anak belajar suatu hal yang paling kecil sekalipun. Tetapi, tidak semua anak yang beruntung memiliki keluarga yang utuh, nyaman, damai, tentram dan sejahtera. Yang bisa disebut dengan keluarga broken home. Keluarga broken home adalah keluarga retak atau sering juga dikatakan sebagai rumah tangga berantakan. Rochendi (2013) menyatakan keluarga adalah dunia keakraban bagi anakanak dan orangtua yang diikat oleh tali batin, sehingga menjadi hal yang penting dari kehidupan. Bagi seorang anak yang hidup dalam lingkungan keluarga yang tidak utuh, kebanyakan dari mereka memiliki sifat dan karakter yang berbeda Hal ini terjadi karena sang anak berfikir hidupnya berbeda dengan anak-anak seusianya.

Menurut Sofyan s. willis dalam bukunya yang berjudul Konseling Keluarga (Family Counseling) bahwa broken home dapat dilihat dari dua aspek yakni; (1) Keluarga tidak utuh yang di sebabkan karena salah satunya meninggal dunia atau bercerai(2)orang tua tidak bercerai tapi dalam kehidupan sehari-hari mereka sibuk sehingga tidak peduli dengan lingkungan sekitarnya. Goode (2007:187) menyatakan broken home terjadi akibat dari perpecahan suatu unit keluarga, terputus atau retaknya struktur keluarga. Penemuan Komnas Anak sepanjang tahun 2011 juga menyebutkan bahwa terdapat 1.851 anak yang melakukan tindak kriminal, dimana tindakan tersebut dilakukan anak sebagai bentuk frustasi akibat dari tidak harmonisnya hubungan dalam keluarganya. Berita - berita seperti ini yang memperkuat stigma masyarakat mengenai anak broken home. Tidak hanya Titus yang mendapat sorotan khusus sebagai anak broken home, seorang gadis 16 tahun di Provinsi Jambi didapati melakukan tindakan kriminal. Dengan menyebutkan latar belakang keluarganya yang tidak harmonis semakin menguatkan pemikiran bahwa anak yang lahir di keluarga broken home pasti tumbuh tanpa perhatian dan akan merasa tidak bahagia, sehingga berkembang menjadi anak yang nakal dan tidak bisa di atur.

Tidak dapat dipungkiri bahwa mempunyai keluarga yang sudah tidak utuh lagi, merupakan salah satu masalah yang paling berat bagi anak, dan berdampak pada hampir semua aspek kehidupannya. Keluarga broken home memberikan pengaruh pada perolehan prestasi akademik anak di sekolah. Prestasi akademik yang diperoleh siswa yang berasal dari keluarga broken home, pada umumnya rendah. Namun meskipun begitu, tidak semua anak yang berasal dari keluarga bercerai memiliki perilaku yang buruk. Seperti halnya Riesy Tane, salah satu anak broken home yang memiliki prestasi yaitu mampu mendapatkan IPK 4,00 dalam masa perkuliahannya. Berdasarkan jabaran ini, peneliti menemukan bahwa terdapat perbedaan prestasi antara siswa yang berasal dari keluarga broken home. Perbedaannya adalah pada siswa yang berprestasi tinggi dan siswa yang berprestasi rendah. Dengan adanya perbedaan ini, mendorong peneliti untuk menganalisis faktor-faktor yang memungkinkan terjadinya perbedaan prestasi akademik tersebut melalui penelitian kualitatif dengan judul "Analisis perbedaan prestasi belajar terhadap Siswa yang Berasal dari Keluarga broken home".

\section{METODOLOGI PENELITIAN}

Penelitian ini berbentuk studi kasus yaitu suatu penelitian kualitatif dengan menghasilkan data deskriptif berupa ucapan (lisan) dan perilaku orang-orang yang sedang diamati. Menurut Moleong, (2017) penelitian kualitatif dengan metode deskriptif yaitu, "Penelitian kualitatif sebagai penelitian yang bermaksud untuk memahami fenomena tentang apa yang dialami oleh subjek penelitian misalnya prilaku, persepsi, motivasi, tindakan dll, secara holistik, dan dengan cara deskritif'. Maka bentuk penelitian yang sesuai data dan relevan, dimana penelitian ini bertujuan untuk 
memperoleh fakta-fakta yang ada tentang analisis perbedaan prestasi pada anak broken home dan bagaimana minat belajar siswa tersebut di kabupaten kampar. Dengan demikian, penelitian kualitatif bukan hanya untuk mendeskripsikan data melainkan deskripsi tersebut merupakan hasil dari pengumpulan data dengan syarat kualitatif yaitu wawancara intens, observasi, dan dokumenetasi.

Pelaksanaanya dilaksanakan secara langsung di daerah kabupaten kampar di dua tempat yaitu lingkungan Universitas Pahlawan Tuanku Tambusai Bangkinang yang mana anak tersebut tidak memiliki keluarga yang utuh di sebabkan karena salah satu orang tuanya meninggal dan SMAN 1 KUOK yang mana siswa ini broken home karena kedua orang tuanya bercerai. Hal ini dilakukan agar peneliti dapat mengetahui bagaimana perbedaan prestasi belajar pada anak yang tidak memiliki keluarga yang utuh tersebut. Penelitian dilaksanakan pada awal desember 2020 sampai pada pertengahan desember 2020 agar peneliti dapat memperoleh informasi yang optimal. Subjek dalam penelitian ini merupakanseorang siswa yang berasal dari keluarga broken home yang mempunyaitingkat prestasi akademik yang tinggi ataupun rendah.

Adapun teknik pengumpulan data dalam penelitian ini adalah: 1. Observasi yang dilaksanakan peneliti tidak terlibat secara langsung dalam kegiatan subjek penelitian yang diamati atau peneliti berperan sebagai non-partisipant observer (Basrowi \& Swandi, 2009:109). 2. Wawancara yang dilakukan peneliti melalui komunikasi langsung antara pewawancara (interviewer) dengan narasumber (Bungin, 2008:108). 3. Analisis dokumen berupa peristiwa yang telah berlalu. Bisa dalam bentuk tulisan, gambar, ataupun karyakarya monumental dari seseorang (Basrowi \& Swandi, 2009:158).

Setelah melakukan pengumpulan datadata yang ada serta menyeleksinya sehingga terhimpun satu kesatuan maka langkah selanjutnya adalah analisa data. Analisa data merupakan suatu upaya untuk mendapatkan dan menata secara sistematis hasil observasi, wawancara dan lainnya dalam meningkatkan kemampuan pemahaman penulis tentang kasus yang diteliti dan menyajikannya sebagai tujuan bagi orang lain. Tujuan dari analisis ini adalah untuk pandangan suatu kejadian yang faktual dan akurat mengenai fakta-fakta yang terjadi selama penelitian.

\section{HASIL PENELITIAN DAN PEMBAHASAN}

Berdasarkan hasil observasi dan wawancara yang dilakukan oleh peneliti, dapat diketahui bahwa, siswa yang berasal dari keluarga yang mengalami broken home, yang mana salah satu dari orang tuanya meninggal dunia. Siswa tersebut tinggal bersama salah satu orang tuanya (ibunya). Pada dasarnya, Siswa yang berasal dari keluarga yang mengalami broken home kebanyakan mengalami dampak academic problem, tapi peneliti menemukan bahwa sang narasumber ini merupakan siswa yang berprestasi. Hal ini karena siswa ini memiliki minat belajar yang tinggi. Pada saat di kampus, siswa ini belajar dengan sungguh-sungguh, selalu memperhatikan gurunya saat sedang menjelaskan, siswa tersebut juga rajin mengerjakan tugas yang diberikan padanya sehingga siswa tersebut mendapat nilai yang tuntas.

Untuk subjek 2, siswa yang berasal dari keluarga broken home yang di sebabkan karena kedua orang tuanya bercerai dan dia memiliki prestasi yang rendah dan memiliki minat belajar yang rendah. Di dalam kelas, siswa ini sering main-main dalam proses belajar mengajar, tidak mau memperhatikan guru pada saat belajar, malas mengerjakan tugas sekolah sehingga sang guru pun kecewa dengan sikap sang anak.

Pada segi perilaku, subjek 1, seorang mahasiswa yang berasal dari keluarga broken home ini berperilaku sangat baik, tidak pernah berperilaku tidak baik. Anak ini tidak suka mengganggu proses brlajar mengajar, tidak mengganggu teman-teman lain yang ada di kelas, sopan terhadap setiap orang, dan juga senantiasa berpenampilan rapi. Tujuan sang anak seperti ini karena baginya sekarang dia hanya mempunyai seorang ibu dalam keluarganya dan tidak ingin membuat ibunya sedih atau marah apabila dia melakukan sebuah kesalahan nantinya. Di sekolah dia menjadi sosok siswa yang rajin, tekun, mentaati peraturan dan aktif serta memperhatikan materi yang di ajarkan oleh gurunya saat proses pembelajaran berlangsung. Siswa tersebut tidak pernah melakukan sebuah tindakan yang melanggar peraturan sekolah seperti : tidak 
masuk kelas, tidak membuat tugas dan tidak pernah menentang guru karena baginya guru itu menjadi sosok pengganti orang tua disekolah.

Untuk subjek 2, dari segi prilaku, anak ini sangatlah nakal. Dia suka mengganggu orangorang di sekitarnya, tidak sopan, penampilannya pun tidak rapi. Sang anak hanya mementingkan dirinya sendiri, tidak memikirkan orang lain. Sang anak tidak mau bertanggung jawab atas apa kesalahan yang sudah dia lakukan, dia tidak peduli terhadap apapun.

Berdasarkan dari segi minat belajar siswa yang berasal dari keluarga broken home dari hasil wawancara dan observasi untuk subjek 1, ditemukan bahwa minat belajar siswa tersebut semakin meningkat karena adanya dorongan motivasi yang diberikan ibunya terhadap mereka. Sehingga baginya ibu menjadi sosok panutan dalam memotivasi belajar mereka, disaat dia sekolah dulu ibunya adalah wanita yang pintar dan disanalah mereka termotivasi oleh ibunya dan ingin menjadi seperti dia. Ibu yang selalu memberikan dorongan terhadap belajar membuat mereka mendapatkan nilai yang sangat memuaskan dan menjadi salah satu siswa berprestasi di sekolah. Ibunya sangat berperan terhadap proses belajarnya dan selalu memberi dorongan sekaligus menjadi guru dalam kehidupan belajar mereka dan selalu mengajarkan arti dari sebuah kehidupan dalam hidupnya. Disekolah tingkat minat belajar siswa yang mengalami keluarga broken home tersebut sangat tinggi, mereka merasa senang dengan materi pembelajaran yang ia sukai, mereka memperhatikan saat guru menerangkan materi pembelajaran dengan baik dan memahami setiap materi yang di pelajari dan mereka juga aktif berdiskusi kelompok dan aktif bertanya ketika saat diskusi. Siswa yang memiliki minat belajar tentunya memiliki perasaan senang, ketertarikan, penerimaan di dalam dirinya, serta terlibat langsung dalam proses pembelajaran berlangsung. Ketertarikan seorang siswa cenderung akan meningkat apabila yang bersangkutan memiliki minat yang tinggi dalam kegiatan belajarnya. Para guru harus mampu menumbuhkan dan mengembangkan minat siswa dalam melakukan kegiatan belajar. Dengan demikian siswa akan memperoleh kepuasan yang baik, selanjutnya dapat menumbuhkan motivasi belajar secara efektif dan produktif ini membuat mereka memiliki tingkat minat belajar yang tinggi. Hasil yang dicapai secara baik oleh siswa dari upaya yang telah dilakukannya dapat memberikan motivasi untuk melakukan tindakan selanjutnya. Perasaan sukses yang ada pada diri seorang siswa akan mendorongnya untuk selalu memelihara dan meningkatkan prestasi belajarnya lebih lanjut.

Untuk subjek 2, minat belajarnya semakin hari semakin berkurang karena tidak adanya dorongan motivasi yang ia dapatkan baik itu dari teman-temannya ataupun dari keluarganya. Orang tuanya sibuk dengan urusan mereka masing-masing. Nilainya di sekolah sangat tidak memuaskan. Dia jarang masuk kelas, terlalu sering duduk di kantin sekolah, membuat kenakalan hampir setiap hari.

Komunikasi antara sang anak dan sang ibu terjalin dengan baik sehingga hubungan mereka selalu baik dan apapun masalah yang terjadi dalam keluarga mereka bisa di selesaikan dengan baik. Karena pada dasarnya, komunikasi itu di bangun atas 3 unsur penting seperti: informan, media, dan penangkap informasi. Jika salah satu dari ketiga hal ini di pisahkan, komunikasi pasti tidak akan sesuai seperti yang di harapkan. Anak ini sangat giat dan semangat dalam belajar karena ia mempunyai cita-cita yang sangat tinggi, ia ingin sekali membahagiakan ibunya dan tidak ingin melihat ibunya susah di hari tua nanti karena selama ini ibulah yang mengasuh, merawat, menafkahi, dan membesarkannya sendirian tanpa sosok seorang ayah, ibu sekaligus menggantikan peran ayahnya sejak ia duduk dibangku kelas 6 SD sampai sekarang karena ayahnya telah meninggal dunia dan ia tinggal bersama ibunya.

Untuk subjek 2, rasa ingin untuk belajar tidak ada dalam diri sang anak, dia tidak bersemangat dan sepertinya sang anak hanya pasrah dengan keadaan yang terjadi pada diri dia. Siswa ini hanya tahu bagaimana dia bahagia pada saat sekarang tanpa memikirkan bagaimana dia ke depannya nanti.

Siswa yang berasal dari keluarga broken home, perhatian orang tua (ibu) terhadap proses kegiatan belajarnya dirumah sangat luar biasa, sang ibu tidak menuntut terlalu banyak terhadap dirinya, Sang ibu lebih mementingkan pendidikan dirinya dari pada hal lain dan sudah mempersiapkan segalanya semenjak ayahnya meninggal dunia. Oleh karena itu, perhatian dari ibu terhadap proses kegiatan belajar 
membuat minat belajar dan perhatiannya terhadap proses pembelajaran semakin meningkat. Menurut Slameto, 2005 : " Minat dan perhatian merupakan hal yang di anggap sama dalam penggunaannya sehari-hari, perhatian siswa merupakan konsentrasi siswa terhadap observasi dan pengertian dengan mengesampingkan yang lainnya. Siswa mempunyai minat pada obyek tertentu maka dengan dia akan memperhatikan obyek tersebut"

Untuk subjek 2, karena orang tuanya terlalu sibuk dengan urusan mereka masingmasing, hal ini membuat sang anak menjadi tertekan. Sang anak merasa tidak satupun dari orang tuanya yang menyayanginya. Tidak ada yang peduli padanya. Siswa ini merasa orang tuanya hanya memikirkan kehidupan mereka masing-masing dan nasib mereka masingmasing.

Berdasarkan hasil wawancara yang di dapat dari siswa berprestasi tinggi yang berasal

\section{Subjek 1}

dari keluarga broken home bahwa dia mengatakan banyak teman memberikan semangat serta memotivasinya dalam belajar. Sehingga dengan motivasi yang di dapat dari temannya menjadikan dia lebih giat dan semangat dalam mengikuti proses kegiatan belajar dan bahkan menjadi salah satu siswa berprestasi disekolah. Dalam kegiatan belajar, motivasi sangat di perlukan baik dari keluarga, guru maupun teman. Motivasi dapat diartikan sebagai totalitas daya penggerak di dalam diri siswa akibat kegiatan belajar, yang menjaga dari kelangsungankegiatan belajar dan memberikan arah pada kegiatan belajar siswa, sehingga tujuan yang di kehendaki oleh subyek belajar itu dapat tercapai" (Sardiman, 2000). Anak yang hidup dalam keluarga broken home yang memiliki prestasi rendah, merasa dirinya yang paling benar. Dia juga merasa hidup sendiri karena tidak ada yang peduli padanya.

\begin{tabular}{|c|c|c|c|}
\hline No & Aspek yang diungkap & Hasil & Ketidaksesuaian \\
\hline 1. & $\begin{array}{l}\text { Emotion } \\
\text { Regulation }\end{array}$ & $\begin{array}{l}\text { Subjek 1 merasa tertekan tinggal } \\
\text { dirumah bersama sang ibu dan merasa } \\
\text { muak terhadap ibu kandungnya. } \\
\text { Subjek } 1 \text { sering melampiaskan perasaan } \\
\text { negatifnya tentang maslaah } \\
\text { keluarganya kepada temantemannya di } \\
\text { sekolah. }\end{array}$ & $\begin{array}{l}\text { Tidak sesuai } \\
\text { Tidak sesuai }\end{array}$ \\
\hline 2. & Impuls control & $\begin{array}{l}\text { Sering membentak, berkata kasar dan } \\
\text { berfikir untuk meninggalkan ibunya } \\
\text { sendirian di rumah. }\end{array}$ & Tidak sesuai \\
\hline 3. & Optimis & $\begin{array}{l}\text { Yakin bahwa akan ada masa indah } \\
\text { setelah masa sulit, merasa keadaan } \\
\text { akan baik-baik saja walau tanpa ayah. }\end{array}$ & Sesuai \\
\hline 4. & Casual analysis & $\begin{array}{l}\text { Mampu berfikir kritis terhadap suatu } \\
\text { masalah, membedakan mana yang baik } \\
\text { dan yang buruk, } \\
\text { Sering merasa putus asa jika terjadi } \\
\text { suatu masalah }\end{array}$ & $\begin{array}{l}\text { Sesuai } \\
\text { Tidak sesuai }\end{array}$ \\
\hline 5. & & $\begin{array}{l}\text { Motivasi yang di peroleh dari orang } \\
\text { lain mampu membuat subjek } 1 \text { merasa } \\
\text { yakin bahwa dia mampu menjadi yang } \\
\text { lebih baik dari yang lain }\end{array}$ & Sesuai \\
\hline
\end{tabular}


Subjek 2

\begin{tabular}{|c|c|c|c|}
\hline No & Aspek yang diungkap & Hasil & Ketidaksesuaian \\
\hline 1. & $\begin{array}{l}\text { Emotion } \\
\text { Regulation }\end{array}$ & $\begin{array}{l}\text { Subjek 1 merasa tertekan tinggal } \\
\text { dirumah bersama sang ibu dan merasa } \\
\text { muak terhadap ibu kandungnya. } \\
\text { Subjek } 1 \text { sering melampiaskan } \\
\text { perasaan negatifnya tentang maslaah } \\
\text { keluarganya kepada temantemannya di } \\
\text { sekolah. }\end{array}$ & Sesuau \\
\hline 2. & Impuls control & $\begin{array}{l}\text { Sering membentak, berkata kasar dan } \\
\text { berfikir untuk meninggalkan ibunya } \\
\text { sendirian di rumah. }\end{array}$ & Sesuai \\
\hline 3. & Optimis & $\begin{array}{l}\text { Yakin bahwa akan ada masa indah } \\
\text { setelah masa sulit, merasa keadaan } \\
\text { akan baik-baik saja walau tanpa ayah. }\end{array}$ & Tidak Sesuai \\
\hline 4. & Casual analysis & $\begin{array}{l}\text { Mampu berfikir kritis terhadap suatu } \\
\text { masalah, membedakan mana yang baik } \\
\text { dan yang buruk, } \\
\text { Sering merasa putus asa jika terjadi } \\
\text { suatu masalah }\end{array}$ & Tidak sesuai \\
\hline 5. & & $\begin{array}{l}\text { Motivasi yang di peroleh dari orang } \\
\text { lain mampu membuat subjek } 1 \text { merasa } \\
\text { yakin bahwa dia mampu menjadi yang } \\
\text { lebih baik dari yang lain }\end{array}$ & Tidak sesuai \\
\hline
\end{tabular}

\section{SIMPULAN}

Saat sekarang, banyak persepsi yang muncul bahwa anak yang hidup di lingkungan keluarga yang broken home memiliki prestasi belajar yang sangat minim. Tapi, persepsi ini tidak bisa lagi di terapkan karena anak broken home juga bisa berprestasi seperti anak lainnya, bahkan bisa menjadi lebih berprestasi. Banyak anggapan yang sering muncul dan memandang sebelah mata anak broken home. Adanya pandangan orang yang selalu menganggap anak broken home adalah anak yang rusak dan hancur. Walaupun opini tersebut terus bergulir, faktanya banyak kisah anak broken home yang bisa menjadi sukses luar biasa, baik dalam pendidikannya maupun dalam karirnya. Berdasarkan hasil yang diperoleh peneliti berkenaan poin yang menjadi patokan dari pembuatan jurnal ini. Hal yang menjadi dasar adanya perbedaan prestasi pada anak broken home di antaranya: Pada siswa yang berprestasi tinggi, hubungan siswa brokenhome dengan keluarga (sang ibu), teman dan gurunya disekolah terjalin dengan baik sedangkan siswa yang berprestasi rendah tidak baik. Minat belajar pada siswa yang berprestasi tinggi semakin meningkat karena adanya dorongan motivasi dari sang ibu begitu juga dengan teman-temannya sementara pada siswa yang berprestasi rendah, minat belajarnya semakin menurun karena kurangnya perhatian yang ia dapatkan dari orang tuanya. Siswa yang berprestasi tinggi mendapatkan perhatian yang lebih dari sang ibu yang sangat luar biasa sedangkan siswa yang berprestasi rendah jarang di pedulikan oleh orang-orang di sekitarnya.

\section{DAFTAR PUSTAKA}

Aziz, M. (2015). Perilaku Sosial Anak Remaja Korban Broken Home Dalam Berbagai Perspektif. Jurnal Al- Ijtimaiyyah, 21.

Basrowi dan Suwandi, 2008. Memahami Penelitian Kualitatif. Jakarta: PT Rineka Cipta

Islamarinda, K. M. (2018). Studi Tentang Resiliensi Siswa Broken Home Kelas VIII di SMPN 3 candi sidoarjo. Bimbingan dan Konseling, 16.

Moleong, L. J. (2017). Metode Penelitian Kualitatif Edisi Revisi. Bandung: PT Remaja Rosdakarya. 
Nugraha, M. L. (2019). Analisis Kesulitan Belajar Matematika Terhadap Siswa Keluarga Broken Home Di SMA Uswatun Hasana Jakarta Timur. Jurnal SAP, 6

Pangestu, B. (2017). Motivasi Berprestasi Siswa Broken Home Di SMAN 2 Banguntapan. Skripsi Bimbingan Konseling Islam, 52.

Rahayu, O. E. (2018). Pengaruh Kondisi Orang Tua Broken Home Terhadap Motivasi Belajar Siswa Dalam Mata Pelajaran IPS Di SMP Negeri 1 Gondanglegi. Jurnal Ilmu Pengetahuan Sosial, 160.

Roy Novianto, A. Z. (2018). Analasis Dampak Broken Home Terhadap Minat Belajar Siswa SMA Santun Untan Pontianak. Pendidikan Ilmu-Ilmu Sosial, 8.

Sharfina Rahmi, M. D. (2014, Maret). Masalah-Masalah Yang Dihadapi Siswa Yang Berasal Dari Keluarga Broken Home Dan Implikasinya Terhadap Program Layanan Bimbingan Dan Konseling. Retrieved from http://ejournal.unp.ac.id/index.thp/konselor

Sofyan S Willis, Konseling Keluarga (Family Counseling), (Bandung: Alfabeta, 2008), h. 66.

Slameto. (2005). Belajar Dan Faktor-Faktor Yang Mempengaruhinya. Jakarta: Rineka Cipta.

Tumiyem, D. d. (2015). Analisis Terhadap Siswa Yang Berasal Dari Keluarga Broken Home . Jurnal Konselor, 10.

Widyastuti Gintulangi, J. P. (2017). Dampak Keluarga Broken Home Pada Prestasi Belajar PKN Siswa Di SMA Negeri 1 Tilamuta Kabupaten Boalemo. Jurnal Riset Dan Pengembangan Ilmu Pengetahuan, 6.

Willis, S. S. (2015). Konseling Keluarga (Family Counseling). Bandung: Alfabeta 